\title{
Nonradioactive Multiplex PCR Screening Strategy for the Simultaneous Detection of Multiple Low-density Lipoprotein Receptor Gene Mutations
}

\author{
Maritha J. Kotze, ${ }^{1}$ Leonora Theart, ${ }^{1}$ Magda Callis, ${ }^{2}$ Armand V. Peeters, ${ }^{1}$ Rochelle Thiart, ${ }^{1}$ and \\ Elzet Langenhoven ${ }^{1}$
}

\footnotetext{
${ }^{1}$ Department of Human Genetics, Faculty of Medicine, University of Stellenbosch, Tygerberg and ${ }^{2}$ Department of Human Genetics, Faculty of Medicine, University of the Orange Free State, Bloemfontein, South Africa
}

\begin{abstract}
We have developed a rapid, nonradioactive screening test enabling the simultaneous analysis of three lowdensity lipoprotein receptor (LDLR) gene mutations (D154N, D206E, and V408M), which together account for familial hypercholesterolemia (FH) in $\sim 90 \%$ of the South African Afrikaner population. The assay is designed so that FH patients, negative for these founder-related mutations (found in descendants of European settlers), subsequently can be screened for unknown mutations in the mutation-rich exon 4 of the LDLR gene. Our screening assay consists of two steps: (1) multiplex allele-specific PCR amplification of exons 4 and 9 , and (2) simultaneous analysis of single- and double-strand conformational polymorphisms in exon 4 by vertical electrophoresis on low crosslinked polyacrylamide gels. The simplicity, specificity, and versatility of the multiplex assay makes it an ideal system for routine screening of FH mutations in large population samples.
\end{abstract}

he mutational heterogeneity of familial hypercholesterolemia ( $\mathrm{FH})$, a common autosomal dominant disease caused by mutations in the low-density lipoprotein receptor (LDLR) gene, ${ }^{(1)}$ complicates disease diagnosis at the DNA level. A molecular diagnosis of $\mathrm{FH}$ was shown to be more accurate than a clinical diagnosis. ${ }^{(2,3)}$ Also, because it may be of more prognostic value, ${ }^{(4)}$ much interest is focused on cost-effective methods of screening for disease-related LDLR gene mutations.

The single-strand conformation polymorphism (SSCP) technique, described by Orita et al., ${ }^{(5)}$ is used most commonly worldwide to screen for mutations. It has also been used to detect the majority of LDLR gene mutations identified to date. ${ }^{(6)}$ This simple and convenient general screening method also is being used for the molecular diagnosis of $\mathrm{FH}$ in heterogeneous populations. ${ }^{(7,8)}$ Mutationspecific screening methods have been developed for the molecular diagnosis of FH in more homogeneous populations, where a small number of mutations account for the disease in the majority of cases. ${ }^{(9-12)}$ The increased prevalence of FH in Afrikaners $(\sim 1 / 80)$ is caused by three founder-related point mutations in the LDLR gene that most likely originated in Europe, ${ }^{(6,8,13,14)}$ and are also present in South Africans of mixed race. ${ }^{(15)}$

In this study we describe the development of an assay for the simultaneous analysis of the three founder-related Afrikaner mutations in a single PCR. With this convenient multiplex amplification refractory mutation system (ARMS)PCR, the use of expensive restriction enzymes, radioactivity, and time-consuming, allele-specific oligonucleotide hybridization methods ${ }^{(9,16)}$ can be avoided. Furthermore, the assay was designed in such a manner that PCR products obtained from samples provided by hypercholesterolemics without the common mutations can be screened subsequently for unknown mutations in the mutation-rich exon $4^{(6)}$ of the LDLR gene. Recently, we have demonstrated that low cross-linked polyacrylamide gels supplemented with $15 \%$ urea are highly sensitive in detecting such singlebase substitutions as heteroduplexes. ${ }^{(17)}$ We have modified these conditions slightly for simultaneous analysis of SSCPs on the same gels. It has been suggested that a combination of heteroduplex and SSCP analyses should bring mutation detection closer to $100 \%$. $^{(18,19)}$

\section{MATERIALS AND METHODS}

\section{Genomic DNA}

Genomic DNA was extracted from blood samples of normal controls and $\mathrm{FH}$ patients heterozygous for previously described LDLR gene defects. ${ }^{(9-11,20,21)}$ The DNA was PCR-amplified and used to standardize mutation detection of the founder-related FH Afrikaner-1 (D206E), -2 (V408M), and -3 (D154N) mutations ${ }^{(9)}$ by ARMS-PCR, ${ }^{(22)}$ and also to establish conditions suitable for simultaneous 
analysis of six known mutations (Table 1 ) in the $3^{\prime}$ half of exon 4 by $\operatorname{SSCP}^{(5)}$ and heteroduplex formation ${ }^{(18)}$ on a single polyacrylamide gel.

\section{Multiplex PCR}

Three common and three ARMS primers of the LDLR gene, ${ }^{(23)}$ specific for the three mutant alleles, were used in the multiplex PCR: COMM 1, 5'-CGAGGCCTCCTGCCCGGTGCTCACC-3'; COMM 2, 5'-GCTCACCTGCAGATCATTCTCTGGG-3'; COMM 3, 5'-GGGACCCAGGGACAGGTGATAGGAC-3'; ARMS 1, 5'-CCCGCCCATACCGCAGTTTTCCTCC-3'; ARMS 2, 5'-AGCCTCATCCCCAACCTGAGGACCA-3'; and ARMS 3, 5'-GGGCCTGCGACAACGACCCCGACTGCGAAA-3'. All reactions were performed in a volume of $50 \mu \mathrm{l}$ containing $\sim 0.5 \mu \mathrm{g}$ of genomic DNA; 2 units of Taq DNA polymerase (Boehringer Mannheim); 1x Taq DNA polymerase buffer (supplied by Boehringer Mannheim); $200 \mu \mathrm{M}$ each dATP, dCTP, dGTP, and dTTP (disodium salt, Boehringer Mannheim); 25 pmoles of primer COMM 1; 50 pmoles of primer ARMS $1 ; 10$ pmoles of primers COMM 2 and ARMS 2; 100 pmoles of primers ARMS 3 and COMM 3; 2 mM tetramethylammonium chloride $\left(\mathrm{Me}_{4} \mathrm{NCl}\right)$; and $15 \%$ glycerol. Reaction mixtures were overlaid with light mineral oil (Sigma, $50 \mu \mathrm{l})$ and subjected to DNA denaturation at $94^{\circ} \mathrm{C}$ for $5 \mathrm{~min}$, and then to two amplification cycles: (1) 15 cycles at $94^{\circ} \mathrm{C}$ for $1 \mathrm{~min}, 62^{\circ} \mathrm{C}$ for $1 \mathrm{~min}, 72^{\circ} \mathrm{C}$ for 2 min; and (2) 20 cycles at $94^{\circ} \mathrm{C}$ for $1 \mathrm{~min}$, $55^{\circ} \mathrm{C}$ for $1 \mathrm{~min}, 72^{\circ} \mathrm{C}$ for $2 \mathrm{~min}$. PCR products were electrophoresed for $3 \mathrm{hr}$ in 3\% Metaphor gels (FMC Bioproducts) or for $2 \mathrm{hr}$ at $100 \mathrm{~V}$ in $10 \%$ polyacrylamide gels, and stained with ethidium bromide.

\section{Heteroduplex-SSCP Analyses}

DNA fragments of $330 \mathrm{bp}$ comprising the 3 '-half of exon 4 of the LDLR gene (the internal control fragment in the multiplex PCR) and spanning six different mutation sites were PCR-amplified according to Kotze et al. ${ }^{(9)}$ Ten microliters of each PCR product was mixed with an equal volume of gel loading buffer ( $95 \%$ formamide, $20 \mathrm{mM}$ EDTA, and $0.05 \%$ bromophenol blue, $0.05 \%$ xylene cyanol), and denatured at $95^{\circ} \mathrm{C}$ for $2 \mathrm{~min}$ and immediately placed on ice. The samples were loaded directly onto $30-\mathrm{cm}$ vertical and 1 -mm-thick $10 \%$ polyacrylamide gels with $1 \%$ cross-linking (\%C, ratio of the percent concentration of $N, N^{\prime}$-methylenebisacrylamide to the concentration of total acrylamide monomer) and run overnight at room temperature at $250 \mathrm{~V} .^{(17)}$ Gels were supplemented with $15 \%$ and $7.5 \%$ urea (Stratagene), respectively, and stained in a solution of $0.6 \times \mathrm{TBE}$ containing $1 \mu \mathrm{g} /$ $\mathrm{ml}$ of ethidium bromide.

\section{RESULTS}

\section{Multiplex PCR Assay}

A dual-purpose multiplex ARMS-PCR assay (see Fig. 1) was developed to identify FH heterozygotes with the FH-1 (D206E), -2 (V408M), or -3 (D154N) mutations, and to subject those without these mutations to a further heteroduplex-SSCP screen of exon 4 of the LDLR gene. The photo shows the allelic differentiation obtained directly after PCR amplification and agarose gel electrophoresis of genomic DNA from individuals heterozygous for the $\mathrm{FH}-1,-2$, and -3 mutations, respectively. With a DNA sample from a control subject, a 330-bp product was derived from the internal control
TABLE 1 Mutations in Exon 4 of the LDLR Gene Analyzed by Heteroduplex-SSCP Analyses of PCR-amplified DNA

\begin{tabular}{|c|c|c|}
\hline Codon change & Nucleotide change & Reference \\
\hline \multicolumn{3}{|c|}{ Single-base substitutions } \\
\hline $\mathrm{D} 154 \mathrm{~N}$ & $\mathrm{G}_{523}-\mathrm{A}$ & 9 \\
\hline D206E & $\mathrm{C}_{681}-\mathrm{G}$ & 9 \\
\hline E207K & $\mathrm{G}_{682}-\mathrm{A}$ & 10 \\
\hline \multicolumn{3}{|c|}{ Small rearrangements } \\
\hline Deletion 197 & delete 3 bp after 651 & 11 \\
\hline Insertion 206 & insert $18 \mathrm{bp}$ after 681 & 20 \\
\hline Deletion 168 & delete 23 bp after 567 & 21 \\
\hline
\end{tabular}

primers only (COMM 1 and COMM 3). When DNA samples of FH-1, -2 , and -3 heterozygotes were used in the PCR reaction, the expected 285-, 100-, and 262bp fragments, respectively, were generated. The presence of the 330-bp exon 4 fragment (internal control) in all tubes indicated that amplification occurred in all of the reactions. The remaining internal control PCR products of hypercholesterolemics without the three known mutations subsequently can be subjected to heteroduplex and SSCP analysis in polyacrylamide gels, to screen for other mutations in exon 4 of the LDLR gene.

\section{Heteroduplex-SSCP}

DNA samples from six FH patients heterozygous for different mutations in exon 4 of the LDLR gene (Table 1) were PCR-amplified and examined simultaneously by heteroduplex and SSCP analyses on the same polyacrylamide gel after ethidium bromide staining. Electrophoresis at room temperature in $1 \% \mathrm{C}$ polyacrylamide gels supplemented with $15 \%$ urea resulted in heteroduplex detection of PCR products in five samples from $\mathrm{FH}$ patients. They were heterozygous for an 18-bp insertion, a 23-bp deletion, a 3-bp deletion, a $\mathrm{C} \rightarrow \mathrm{G}$-base change at codon 206 (D206E), and a $\mathrm{G} \rightarrow$ A-base change at codon 207 (E207K), respectively. However, none of these mutations could be detected by SSCP analysis (data not shown). Lowering the urea concentration to $7.5 \%$ did not affect the number of mutations detectable by heteroduplex analysis. However, with the lowering of the urea concentration, three of the mutations (one of which was not detected by heteroduplex analysis) could be detected by SSCP. The combined screening approach thus enabled detection of all six mutations by heteroduplex (18-bp insertion, 23-bp deletion, 3-bp deletion, D206E, E207K) and/or SSCP (18-bp insertion, 23-bp deletion, D154N) analysis on a single polyacrylamide gel (Fig. 2).

PCR-amplified DNA, spanning the three point mutations analyzed by heteroduplex-SSCP, was loaded onto both sides of the same gel shown in Figure 2, to test the reproducibility of the bands obtained in 1\% C polyacrylamide gels supplemented with $7.5 \%$ urea. Although the heteroduplexes resulting from mutations D206E (lanes 4,8) and E207K (lanes 


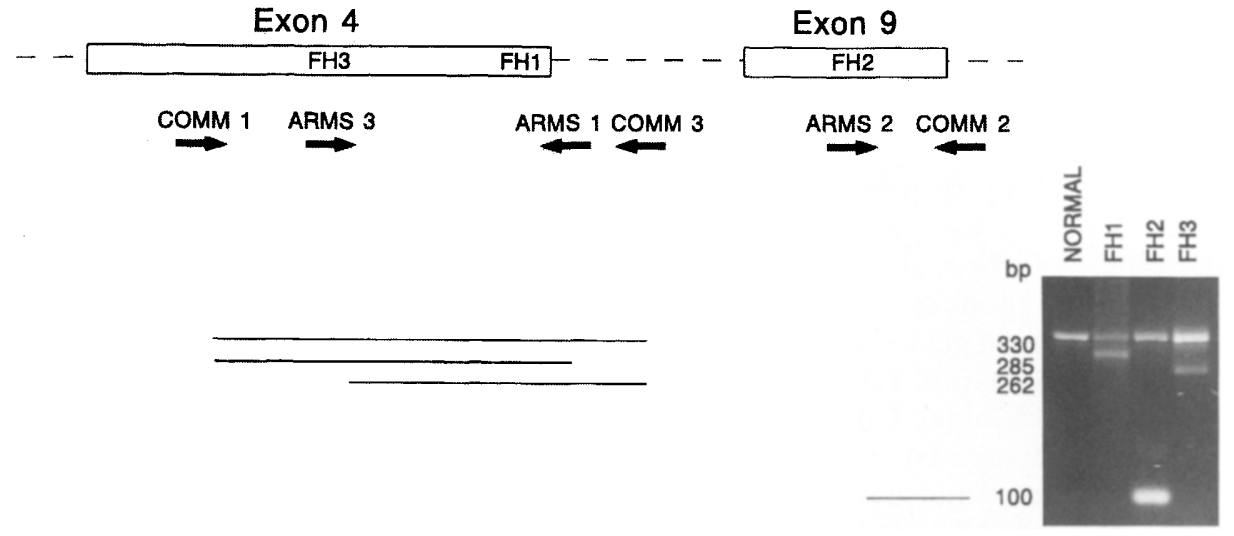

FIGURE 1 Analysis of the FH Afrikaner-1 (D206E), -2 (V408M), and -3 (D154N) mutations by multiplex PCR and gel electrophoresis. The relative positions of the three mutations, and the allele-specific (ARMS) primers and common (COMM) primers are indicated on the partial map of the LDLR gene. (Left to right) The four lanes in the agarose gel contain amplified DNA from individuals without the three mutations, heterozygous for the FH1 mutation, heterozygous for the FH2 mutation, and heterozygous for the FH3 mutation, respectively. The sizes of the amplification products are shown in base pairs (bp).

2,10 ) could be observed in all four lanes, the bands are less clear on the right side of the gel. This phenomenon probably can be ascribed to impurities in the gel. Similar smearing, which interferes with the analysis, was observed when the same gel mix was used for several weeks. The aberrant SSCP pattern generated by mutation D154N, as characterized by an additional band between the two normal alleles, is shown in Figure 2, lanes 3 and 9. Although the same amount of PCR product was loaded in both lanes, less double-stranded DNA is observed in lane 3 compared with lane 9. A smaller proportion of the DNA loaded in lane 3 probably renatured after the denaturation step, resulting in visualization of additional single-strand conformations in this lane.

\section{DISCUSSION}

The multiplex PCR assay described in this study provides a rapid and reliable method for routine screening of FH-related mutations in large population samples, provided suitable precautions are taken to circumvent possible mistypings. Detection of the desired PCR products and specificity of the reaction were found to be largely dependent on the annealing temperature used. Furthermore, different primer sets (and also different batches of the same primer sets) were amplified with slightly different efficiencies. The largest, 330-bp fragment of exon 4 was amplified preferentially when annealing temperatures ranged between $60^{\circ} \mathrm{C}$ and $68^{\circ} \mathrm{C}$, resulting in failure to amplify the 285- and/or 262-bp fragments (or in the presence of very faint bands). This competition priming was reduced by lowering the annealing temperature to $55^{\circ} \mathrm{C}$ after the first $15 \mathrm{cy}$ cles. Separate amplification of the various primer sets has shown that the 330bp internal control PCR fragment was not obtained at this temperature, whereas the smaller exon 4 fragments specific for the FH-1 (D206E) and FH-3 (D154N) mutations were amplified effectively (data not shown). The addition of glycerol in the $\mathrm{PCR}^{(24)}$ was found to further enhance the amplification of the 285-bp FH-1 mutation-specific fragment, whereas the addition of an excess of the ARMS 3 and COMM 3 primers (and limiting the COMM 1 primer) improved the yield of the 262-bp fragment in FH heterozygotes with the FH-3 mutation. Standardization of the multiplex assay was complicated by failure to obtain this 262-bp fragment at an intensity comparable to that of the other bands. For this reason, the length of the ARMS 3 primer was increased to 30 nucleotides compared with the 25-nucleotide lengths of all of the other primers. Use of a 20-nucleotide ARMS 3 primer (5'-CAACGACCCCGACTGCGAAA-3') resulted in complete failure to amplify the expected 252 bp fragment in the multiplex PCR (data not shown). Thus, it is clear that primer length can be varied to increase or decrease selectively the yield of specific PCR products during multiplex reactions. Amplification of the $100-\mathrm{bp}$ frag- ment specific for the FH-2 mutation (V408M) in exon 9 occurred independently of the above reactions, and the specificity of the reaction was increased by the introduction of an additional mismatch near the 3 ' end of primer ARMS 2 to avoid false-positive results. ${ }^{(15)}$ We also included tetramethylammonium chloride $\left(\mathrm{Me}_{4} \mathrm{NCl}\right)$ in the multiplex PCR reaction, because it eliminates the preferential melting point of AT versus GC base pairs. It also reduces the presence of nonspecific fragments caused by mispriming. ${ }^{(25)}$

The multiplex ARMS-PCR can detect FH patients heterozygous for one or two of the Afrikaner mutations but cannot distinguish heterozygotes from true ho-

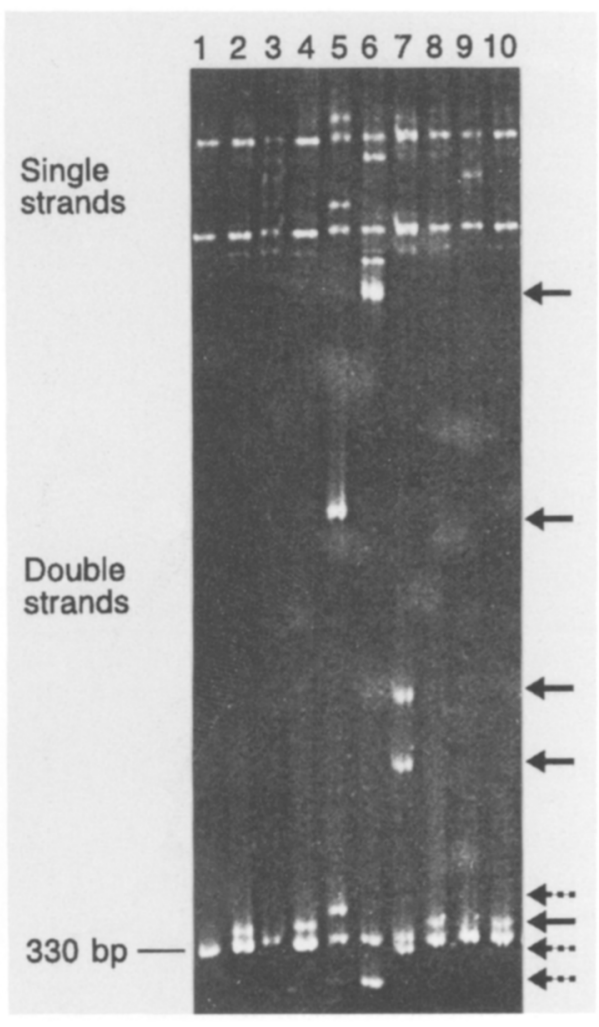

FIGURE 2 Heteroduplex-SSCP analyses of the six known mutations in the LDLR gene. PCR products of $330 \mathrm{bp}$ were electrophoresed on $10 \%(1 \%$ C) polyacrylamide gels supplemented with $7.5 \%$ urea, and were subsequently stained with ethidium bromide. (Lane 1) PCR-amplified DNA from a mutation-negative control; (lanes 2,10) PCR products from $\mathrm{FH}$ patients heterozygous for mutations E207K; (lanes 3,9) D154N; (lanes 4,8) D206E; (lane 5) an 18-bp insertion at codon 206; (lane 6) A 23-bp deletion at codon 168; and (lane 7) A 3-bp deletion at codon 197 were analyzed. Homoduplexes (broken arrows) and heteroduplexes (solid arrows) observed in double-stranded DNA are indicated on the right side of the gel. 
mozygotes with two identical LDLR gene mutations. Subsequent restriction enzyme analysis of PCR products can allow an accurate molecular diagnosis of these relatively rare cases. ${ }^{(9)}$ Because an unequivocal clinical diagnosis of $\mathrm{FH}$ usually can be made in homozygotes, we focused the molecular diagnosis of $\mathrm{FH}$ on heterozygotes whose clinical diagnoses may be complicated by variability in phenotypic expression. ${ }^{(2-4)}$ This screening approach scaled down the cost of a molecular diagnosis of $\mathrm{FH}$ in Afrikaners $^{(26)}$ to one-fifth the amount needed previously for restriction enzyme and/or oligonucleotide hybridization analysis. ${ }^{(9)}$

Knowledge that exon 4 of the LDLR gene is particularly mutation-rich and appears to be prone to various types of mutational events ${ }^{(6-8)}$ was implemented in our screening strategy. The 330-bp internal control fragment comprising the $3^{\prime}$ half of exon 4 was specifically coamplified in the multiplex PCR to avoid false-negative results in the ARMS assay and also to subsequently screen this PCR product for $\mathrm{FH}$-related mutations other than the three founder-related Afrikaner mutations. About $20 \%$ of LDLR mutations occur in this region of the gene. ${ }^{(6)}$ DNA samples from patients heterozygous for six different mutations in exon 4 were used to establish conditions suitable for heteroduplex and SSCP analyses on a single polyacrylamide gel. Electrophoresis of denatured PCR products, under conditions that were previously shown to be highly sensitive in detecting single-base substitutions as heteroduplexes in undenatured DNA, ${ }^{(17)}$ indicated that the urea concentration of $15 \%$ in the low cross-linked polyacrylamide gels is too high for SSCP analysis of the exon 4 LDLR gene fragments. The lowering of the urea concentration to $7.5 \%$ allowed mutation detection by both SSCP and heteroduplex analysis, because sufficient reannealing of DNA strands occurred to simultaneously allow the analysis of heteroduplex formation in the faster-migrating, double-stranded DNA on the same polyacrylamide gel.

All of the mutations analyzed could be detected, thus illustrating that a combination of SSCP and heteroduplex analyses is highly sensitive in detecting small mutations. Failure to detect the small 3-bp deletion by SSCP indicated that the relatively large size of the exon 4 fragment being analyzed influences the like- lihood of detecting mutations in PCRamplified DNA negatively, as has been shown previously by others. ${ }^{(27)}$ The 3-bp deletion at codon 197 could readily be detected as an SSCP in a smaller PCR product of $237 \mathrm{bp}$ (data not shown). Heteroduplex formation does not appear to be equally sensitive to the size of the PCR product analyzed and can be detected in relatively large PCR fragments by proportionally increasing electrophoresis times. $^{(28,29)}$

Although it remains to be investigated as to how valuable combined heteroduplex-SSCP analyses are in improving detection of small mutations, this method nevertheless allows optimal use of the mutation-rich exon 4 PCR product being obtained in the multiplex PCR in patients without the three founder-related Afrikaner mutations. It also has the advantage of being technically straightforward and can be carried out without the use of isotopes because the DNA is stained with ethidium bromide. ${ }^{(30)}$ Furthermore, including the analysis of the faster-migrating, double-stranded DNA in the screening approach gives an indication of the type of mutation involved. A mutant homoduplex resulting from an insertion in PCR-amplified DNA usually migrates more slowly on polyacrylamide gels than the normal double-stranded PCR product, whereas a mutant homoduplex resulting from a deletion usually migrates faster. An exception to this general pattern was, however, recently observed in the adenomatous polyposis coli gene, where the mutant homoduplex band resulting from an AT base pair insertion migrated faster than the normal homoduplexes in the unaffected individuals. ${ }^{(31)}$ Heteroduplex bands were invariably found to migrate slower than homoduplex bands.

A further advantage of our multiplex screening strategy is that other mutation-specific ARMS primers can be included in the PCR for mutation detection in other exons or other genes, provided that different-sized DNA fragments are generated. For example, inclusion of the ARMS primers described by Wenham et al. ${ }^{(32)}$ for detection of the apolipoprotein (apo) $\mathrm{B}_{3500}$ mutation, ${ }^{(33)}$ causing familial defective apo B-100 (FDB), ${ }^{(34)}$ generates the expected 187-bp ARMS product in FDB heterozygotes (data not shown). This allows differential molecular diagnoses of $\mathrm{FH}$ and FDB, ${ }^{(35)}$ which share similar clinical characteristics. Because primers specific for mutations not prevalent in the study population similarly can be excluded from the PCR, the multiplex screening strategy described in this study is versatile and should be useful in various population groups.

The recent demonstration that mutational heterogeneity in the LDLR gene influences the phenotypic expression of $\mathrm{FH}^{(4)}$ has emphasized the need for rapid PCR assays that may assist in the assessment of an individual's risk for the development of coronary heart disease (CHD). Mutation detection by multiplex ARMS-PCR, followed by heteroduplexSSCP analyses in subjects without founder-related mutations; is an effective screening method for known and new LDLR gene mutations. This screening approach recently has resulted in the identification of the first molecularly characterized de novo mutation in exon 4 of the LDLR gene. ${ }^{(20)}$ Conditions suitable for the detection of the six known mutations in exon 4 of the LDLR gene by heteroduplex and SSCP analyses were determined and can now be applied to other genes or other regions in the LDLR gene to screen various populations for mutations underlying genetic disease. Our data also provide evidence in favor of the hypothesis that addition of mildly denaturing solvents (urea in this case) can amplify the tendency of mismatched bases to produce conformational changes and thereby increase the differential migration of normal and mutant fragments during gel electrophoresis. $^{(5,29,36)}$

\section{ACKNOWLEDGMENTS}

We acknowledge J. Brusnicky for critical reading of this manuscript and A. Micklem for technical assistance. The work was supported by the South African Medical Research Council, the Universities of Stellenbosch and the Orange Free State, and the Cape Provincial Administration.

\section{REFERENCES}

1. Goldstein, J.L. and M.S. Brown. 1989. Familial hypercholesterolemia. In The metabolic basis of inherited disease (ed. C.R. Scriver, A.L. Beaudet, W.S. Sly, and D. Valle) pp. 1215-1250. McGraw-Hill, New York.

2. Kotze, M.J., E. Langenhoven, J.A. Kriek, C.J.J. Oosthuizen, and A.E. Retief. 1992. 
DNA screening of hyperlipidemic Afrikaners for familial hypercholesterolemia. Clin. Genet. 42: 43-46.

3. Koivisto, P.V.I., U.-M. Koivisto, T.A. Miettinen, and K. Kontula. 1992. Diagnosis of heterozygous familial hypercholesterolemia. DNA analysis complements clinical examination and analysis of serum lipid levels. Arterioscler. Thromb. 12: 584592.

4. Kotze, M.J., W.J.S. de Villiers, K. Steyn, J.A. Kriek, A.D. Marais, E. Langenhoven, J.S. Herbert, J.F. Graadt Van Roggen, D.R. van der Westhuyzen, and G.A. Coetzee. 1993. Phenotypic variation among familial hypercholesterolemics heterozygous for either one of two Afrikaner founder LDL receptor mutations. Arterioscler. Thromb. 13: $1460-1468$.

5. Orita, M., Y. Suzuki, T. Sekiya, and K. Hayashi. 1989. Rapid and sensitive detection of point mutations and DNA polymorphisms using the polymerase chain reaction. Genomics 5: 874-879.

6. Hobbs, H.H., M.S. Brown, and J.L. Goldstein. 1992. Molecular genetics of the LDL receptor gene in familial hypercholesterolemia. Hum. Mutat. 1: 445-466.

7. Gudnason, V., Y.T. Mak, J. Betteridge, S.N. McCarthy, and S. Humphries. 1993. Use of the single-strand conformational polymorphism method to detect recurrent and novel mutations in the low-density lipoprotein receptor gene in patients with familial hypercholesterolemia: Detection of a novel mutation $\mathrm{Asp}_{200^{-}}$Gly. Clin. Invest. 71: 331-337.

8. Gudnason, V., L. King-Underwood, M. Seed, X.M. Sun, A.K. Soutar, and S.E. Humphries. 1993. Identification of recurrent and novel mutations in exon 4 of the LDL receptor in patients with familial hypercholesterolemia in the United Kingdom. Arterioscler. Thromb. 13: 56-63.

9. Kotze, M.J., E. Langenhoven, L. Warnich, L. du Plessis, and A.E. Retief. 1991. The molecular basis and diagnosis of familial hypercholesterolemia in South African Afrikaners. Ann. Hum. Genet. 55: 115121.

10. Leitersdorf, E., E.J. Tobin, J. Davignon, and H.H. Hobbs. 1990. Common lowdensity lipoprotein receptor mutations in the French Canadian population. J. Clin. Invest. 85: 1014-1023.

11. Meiner, V., D. Landsberger, N. Berkman, A. Reshef, P. Segal, H.C. Seftel, D.R. van der Westhuyzen, M.S. Jeenah, G.A. Coetzee, and E. Leitersdorf. 1991. A common Lithuanian mutation causing familial hypercholesterolemia in Ashkenazi Jews. Am. J. Hum. Genet. 49: 443-449.

12. Koivisto, U-M., H. Turtola, K. Aalto-Setälä, B. Top, R.R. Frants, P.T. Kovanen, A.-C. Syvänen, and K. Kontula. 1992. The familial hypercholesterolemia (FH)-North Karelia mutation of the low density li- poprotein receptor gene deletes seven nucleotides of exon 6 and is a common cause of $\mathrm{FH}$ in Finland. J. Clin. Invest. 90: 219-228.

13. Defesche, J.C., D.E. van Diermen, P.J. Lansberg, R.J Lamping, P.W.A Reymer, M.R. Hayden, and J.J.P. Kastelein. 1993. South African founder mutations in the low-density lipoprotein receptor gene causing familial hypercholesterolemia in the Dutch population. Hum. Genet. 92: 567-570.

14. Schuster, H., H.J. Fischer, C. Keller, G. Wolfram, and N. Zöllner. 1993. Identification of the 408 valine to methionine mutation in the low density lipoprotein receptor in a German family with familial hypercholesterolemia. Hum. Genet. 91: 287-289.

15. Kotze, M.J., E. Langenhoven, L. Theart, $O$. Loubser, A. Micklem, and C.J.J. Oosthuizen. 1995. Recurrent LDL receptor mutation causes familial hypercholesterolemia in South African Coloureds and Afrikaners. S. Afr. Med. J. (in press).

16. Graadt van Roggen, J.F., D.R. van der Westhuyzen, A.D. Marais, W. Gevers, and G.A. Coetzee. 1991. Low density lipoprotein receptor founder mutations in Afrikaner familial hypercholesterolemic patients: A comparison of two geographical areas. Hum. Genet. 88: 204-208.

17. Peeters, A.V. and M.J. Kotze. 1994. Improved heteroduplex detection of singlebase substitutions in PCR-amplified DNA. PCR Methods Applic. 4: 188-190.

18. White, M.B., M. Carvalho, D. Derse, S.J. O'Brien, and M. Dean. 1992. Detecting single base substitutions as heteroduplex polymorphisms. Genomics 12: 301-306.

19. Cotton, R.G.H. 1993. Current methods of mutation detection. Mutat. Res. 285: 125-144.

20. Kotze, M.J., L. Theart, A.V. Peeters, and E. Langenhoven. 1995. A de novo duplication in the LDL receptor gene. Hum. Mutat. (in press).

21. Peeters, A.V., L.F. Van Gaal, L. Theart, E. Langenhoven, and M.J. Kotze. 1995. Two novel frameshift mutations in the low density lipoprotein receptor gene generated by endogenous sequence-directed mechanisms. Hum. Genet. (in press).

22. Newton, C.R., A. Graham, L.E. Heptinstall, S.J. Powell, C. Summers, N. Kalsheker, J.C. Smith, and A.F. Markham. 1989. Analysis of any point mutation in DNA. The amplification refractory mutation system (ARMS). Nucleic Acids Res. 17: 2503-2516.

23. Yamamoto, T., C.G. Davis, M.S. Brown, W.J. Schneider, M.L. Casey, J.L. Goldstein, and D.W. Russell. 1984. The human LDL receptor: A cysteine-rich protein with multiple Alu sequences in its mRNA. Cell 39: 27-38.

24. Lu, Y.H. and S. Negre. 1993. Use of glyc- erol for enhanced efficiency and specificity of PCR amplification. Trends Genet. 9: 297.

25. Ugozzoli, L. and B. Wallace. 1992. Application of allele-specific polymerase chain reaction to the direct determination of ABO blood group genotypes. Genomics 12: $670-674$.

26. Kotze, M.J., E. Langenhoven, L. Theart, M.P. MarX, and C.J.J. Oosthuizen. 1994. Report on a molecular diagnostic service for familial hypercholesterolemia in Afrikaners. Genet. Counselling 5: 15-21.

27. Sheffield, V.C., J.S. Beck, A.E. Kwitek, D.W. Sandstrom, and E.M. Stone. 1993. The sensitivity of single-strand conformation polymorphism analysis for the detection of single base substitutions. Genomics 16: 325-332.

28. Perry, D.J. and R.W. Carrell. 1992. Hydrolink gels: A rapid and simple approach to the detection of DNA mutations in thromboembolic disease. J. Clin. Pathol. 45: $158-160$.

29. Ganguly, A., M.J. Rock, and D.J. Prockop. 1993. Conformation-sensitive gel electrophoresis for rapid detection of single-base differences in double-stranded PCR products: Evidence for solvent-induced bends in DNA heteroduplexes. Proc. Natl. Acad. Sci. 90: 10325-10329.

30. Yap, E.P.H. and J.O. McGee. 1992. Nonisotopic SSCP detection in PCR products by ethidium bromide staining. Trends Genet. 8: 49.

31. Kotze, M.J., J.J. Grobbelaar, and M.V. Madden. 1995. Identification of a novel single base insertion in the adenomatous polyposis coli gene. Hum. Mutat. (in press).

32. Wenham, P.R., C.R. Newton, R.S. Houlston, and W.H. Price. 1991. Rapid diagnosis of familial defective apolipoprotein B-100 by amplification refractory mutation system. Clin. Chem. 37: 1983-1987.

33. Soria, L.F., E.H. Ludwig, H.R.G. Clarke, G.L. Vega, S.M. Grundy, and B.J. McCarthy. 1989. Association between a specific apolipoprotein B mutation and familial defective apolipoprotein B-100. Proc. Natl. Acad. Sci. 86: 587-591.

34. Innerarity, T.L., R.W. Mahley, K.H. Weisgraber, T.P. Bersot, R.M. Krauss, G.L. Vega, S.M. Grundy, W. Friedl, J. Davignon, and B.J. MacCarthy. 1993. Familial defective apolipoprotein B-100: A mutation of apolipoprotein B that causes hypercholesterolemia. J. Lipid Res. 31: 1337-1349.

35. Kotze, M.J. (unpubl.).

36. Glavac, D. and M. Dean. 1993. Optimization of the single-strand conformation polymorphism (SSCP) technique for detection of point mutations. Hum. Mutat. 2: 404-414.

Received February 27, 1995; accepted in revised form April 17, 1995. 


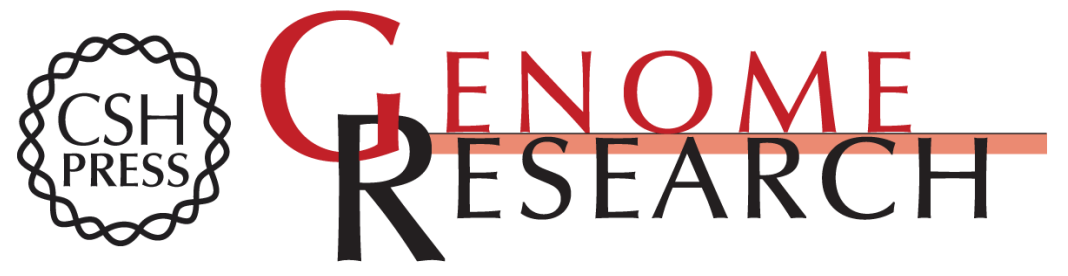

\section{Nonradioactive multiplex PCR screening strategy for the simultaneous detection of multiple low-density lipoprotein receptor gene mutations.}

M J Kotze, L Theart, M Callis, et al.

Genome Res. 1995 4: 352-356

References This article cites 30 articles, 7 of which can be accessed free at:

http://genome.cshlp.org/content/4/6/352.full.html\#ref-list-1

License

Email Alerting Receive free email alerts when new articles cite this article - sign up in the box at the Service top right corner of the article or click here.

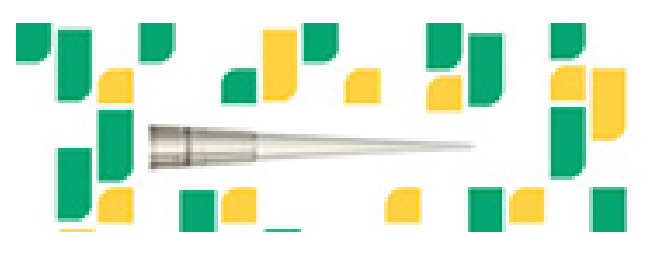

Focused on your science.

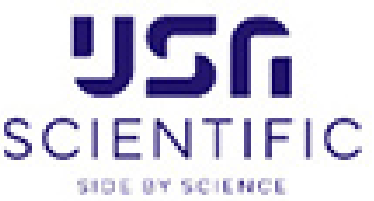

To subscribe to Genome Research go to:

https://genome.cshlp.org/subscriptions 